\title{
Malignant eccrine poroma: report of three cases
}

\author{
J F RYAN,* C R DARLEY, $\dagger$ D J POLLOCK* \\ From the Departments of * Morbid Anatomy and †Dermatology, The London Hospital, London
}

SUMMARY The characteristic clinical and histological features of three cases of malignant eccrine poroma are discussed, in addition to the metastatic disease that had occurred in two cases. These cases were compared with previously reported cases of malignant eccrine poroma that had metastasised, and it is suggested that a strict classification of malignant eccrine sweat gland tumours should be made.

Malignant eccrine poroma was first described in 1963 by Pinkus and Mehregan, using the term epidermotropic eccrine carcinoma. ${ }^{1}$ It is regarded as the rare malignant counterpart of eccrine poroma, a benign tumour of the intraepidermal eccrine sweat duct (acrosyringium), which was first described in $1956 .{ }^{2}$

Recently we saw three patients who had several characteristic clinical and histopathological features of this tumour. Two of the patients showed histologically confirmed evidence of metastatic disease.

\section{Case reports}

\section{CLINICAL FEATURES}

\section{Case 1}

The early clinical course of this patient has been reported previously. ${ }^{3}$

A caucasian man first noticed a warty area on the left buttock in 1974, when aged 51. This gradually increased in size over the next five years, until he presented in 1979 with a scaling warty eruption affecting most of the left buttock. Biopsy specimens indicated intraepidermal squamous cell carcinoma. Despite multiple superficial doses of radiation to the affected areas, by 1980 the tumour covered most of the left buttock and extended on to the thigh. The tumour consisted of hyperkeratotic nodules, which were confluent in many areas. There was pronounced surrounding erythema. On the posterior thigh there was a large erythematous papillomatous plaque from which many warty excrescences protruded. In some areas the nodules were smooth and translucent; in other areas they were eroded or ulcerated. There was oedema of the left leg and genitalia. A further biopsy specimen showed malignant eccrine poroma.

The tumour was excised and a split skin graft applied. This first graft failed and severe necrotising fasciitis with some underlying myonecrosis subsequently occurred. After this infection had been treated regrafting was successfully performed. The patient returned 10 months later with recurrent tumour at the edges of the graft and oedema of the left leg and genitalia. In view of the failure of surgery to cure the disease further radiotherapy was performed. Over the next two years the tumour continued to spread slowly, despite radiotherapy and a further attempt at excision and skin grafting, and became ulcerated in the left groin. The patient was readmitted to hospital in January 1983 with tumour now affecting most of the left buttock, groin, and thigh, with extension on to the lower abdomen (fig 1a). There was oedema of both legs and the genitalia. He complained most, however, of pain in the right hip. This was explored surgically and showed no evidence of tumour.

He died in June 1983 from loss of blood after erosion of the tumour into the left femoral artery. There was no clinical evidence of tumour metastases at the time of death.

\section{Case 2}

A 76 year old caucasian man presented in 1982 with a two year history of a verrucous crusted plaque on the outer aspect of the right thigh, now $8 \times 8 \mathrm{~cm}$ in area (fig lb). There was considerable erythema and a halo of papules (fig 2), which had extended a further $2 \mathrm{~cm}$ around the lesion. A biopsy was performed and showed malignant eccrine poroma. Ten months after excision of the lesion an enlarged right inguinal lymph node was found, and a block dissection of the right inguinal lymph nodes was undertaken. He returned once to outpatients when no recurrence was noted. He was lost to subsequent follow up.

\section{Case 3}

An 87 year old caucasian woman presented in 1982 with an ulcerated area on her left flank. She had 

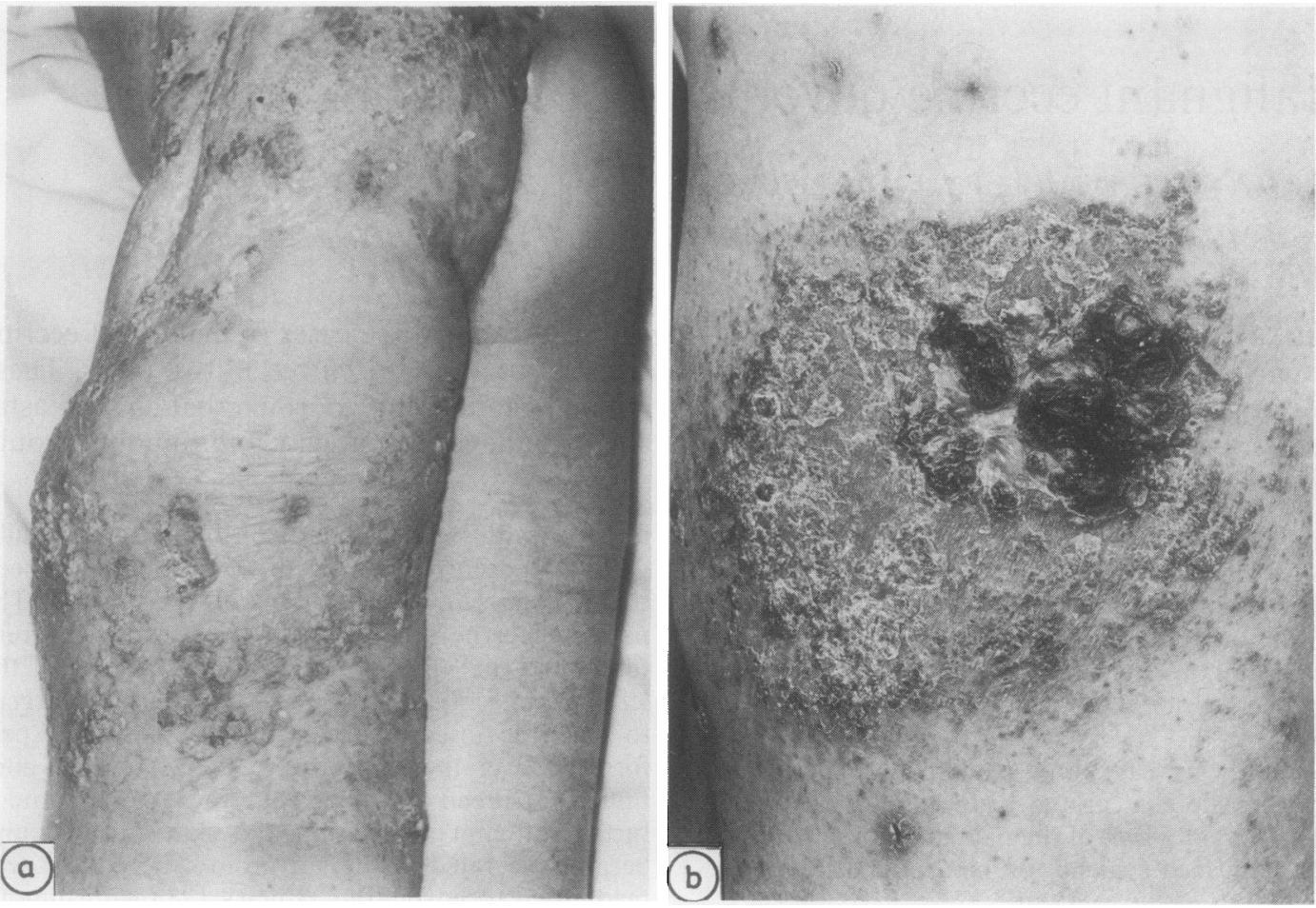

Fig 1 (a) Case 1. Lymphoedema of left leg. Area at top of left thigh has been previously excised and grafted. There are waxts excrescences scattered over thigh.

Fig 1 (b) Case 2. Lesion on thigh showing erythema with crusting and hyperkeratosis, surrounded by warty papules and nodules.

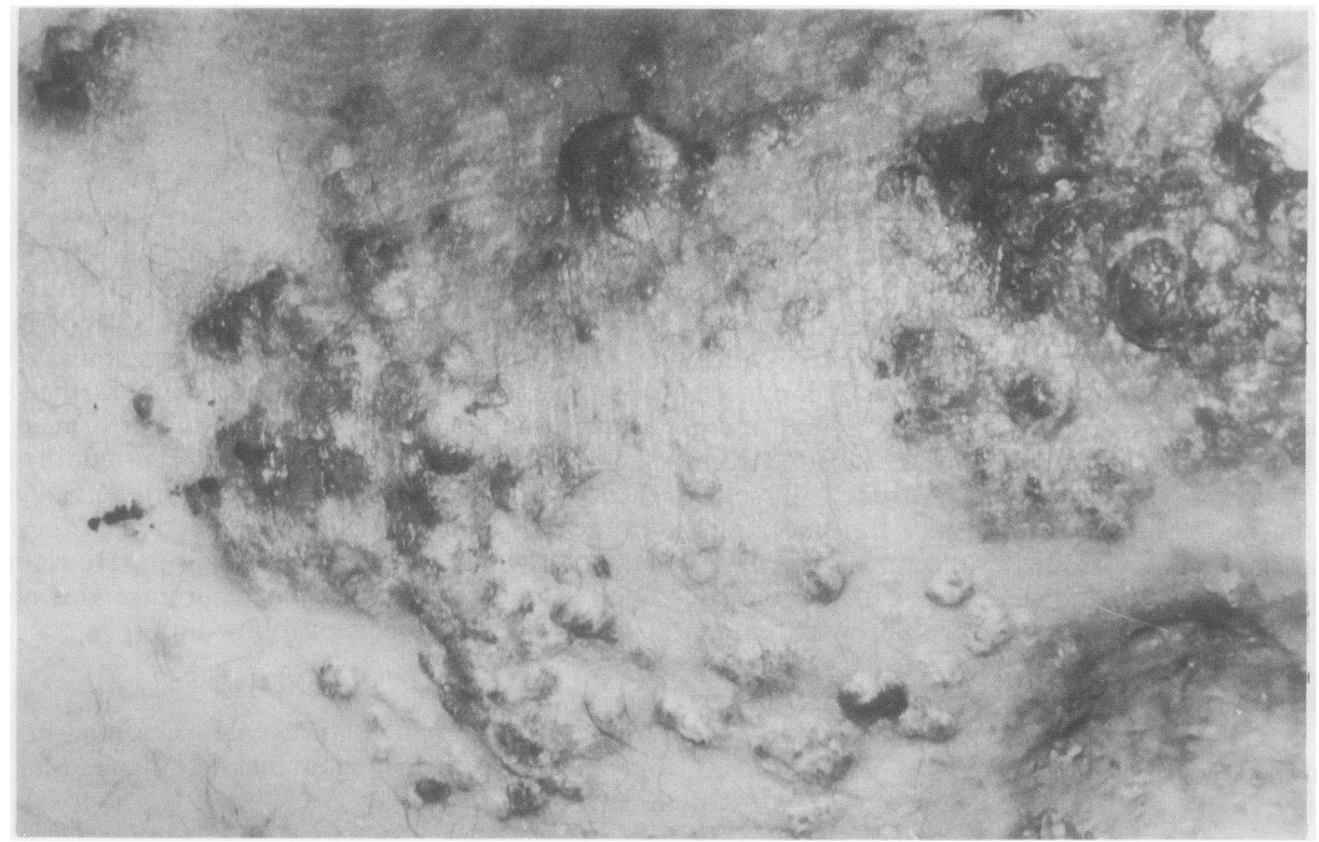

Fig 2 Case 2. Close up to show warty and translucent nodules. 


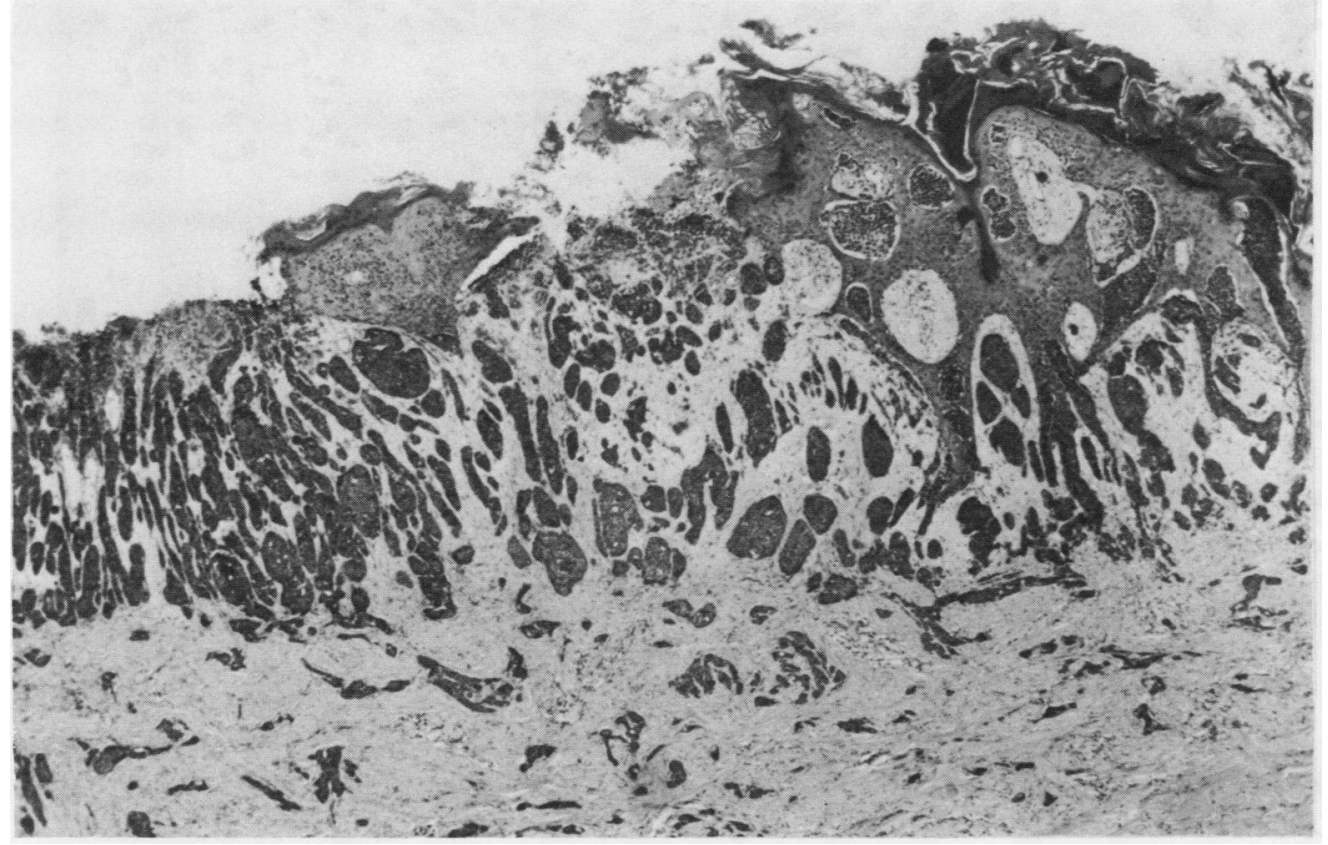

Fig 3 Case 3. Hyperkeratosis, acanthosis, and ulceration of epidermis, with tumour within epidermis and dermis. $\times 28$.

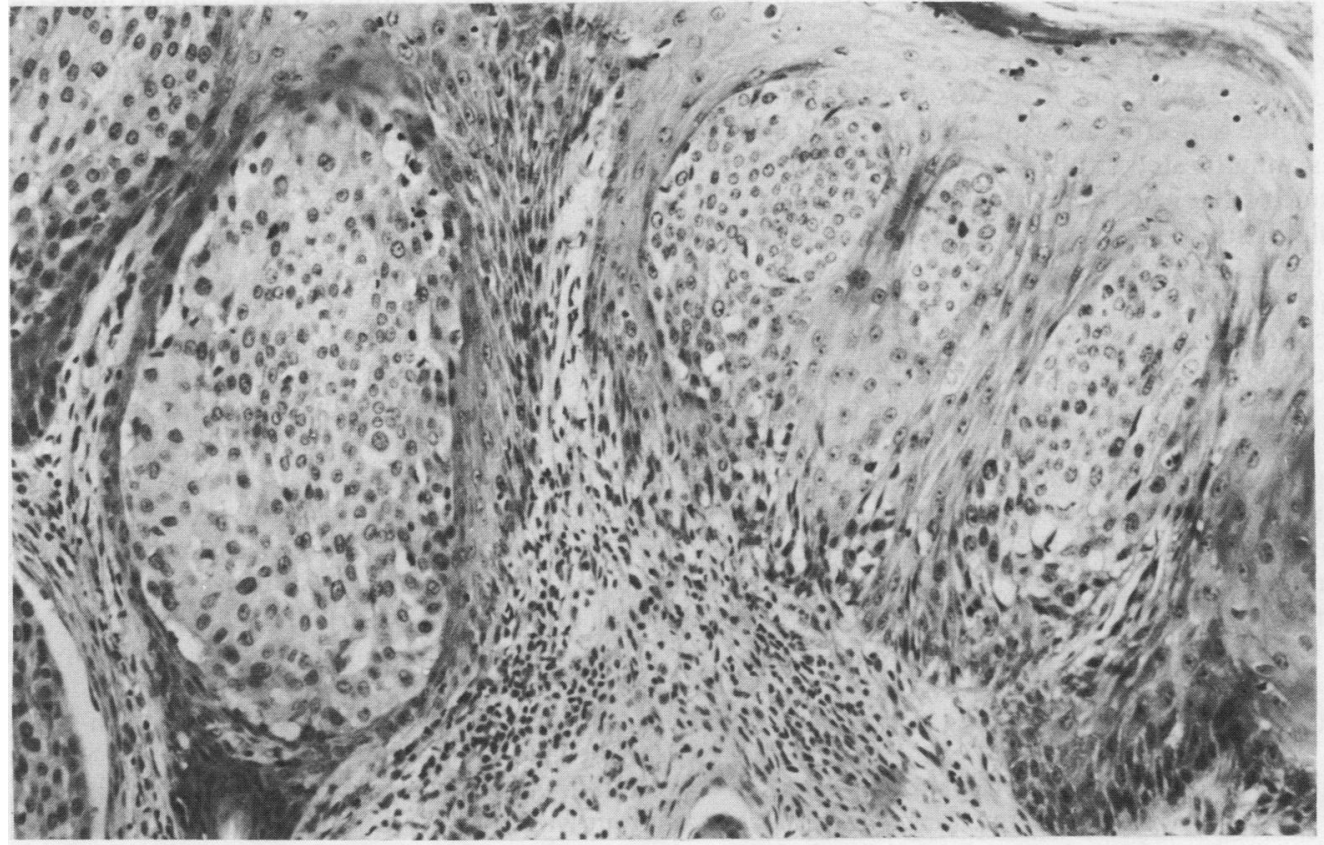

Fig 4 Case 1. Intraepidermal tumour. $\times 140$. 


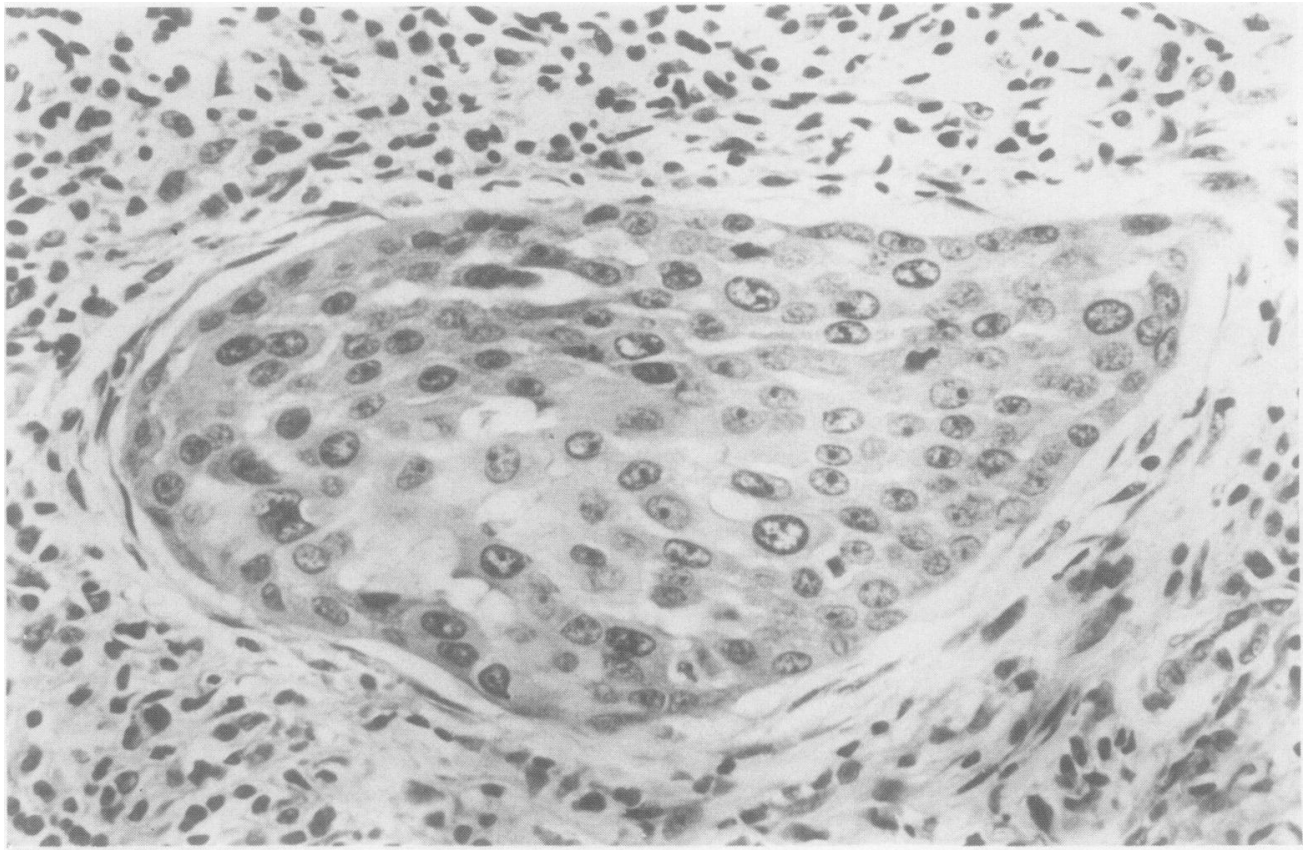

Fig 5 Case 1. Intralymphatic tumour. Cellular and nuclear detail can be observed. $\times 560$.

noticed a "mole" in that area for many years but she had now developed an ulcer $2.5 \mathrm{~cm}$ in diameter, which was surrounded by erythematous skin. A biopsy was performed and showed malignant eccrine poroma. The lesion was excised but there was a recurrence at the ends of the scar after a few months. By early 1983 there was an indurated erythematous scaly plaque on the left side of the back measuring $14 \times 12 \mathrm{~cm}$, with central ulceration. There was a similar area on the left anterolateral chest wall $(20 \times 10 \mathrm{~cm})$, which extended under the left breast. At this site there were multiple translucent papules. There was a palpable left axillary lymph node but no other clinical evidence of metastasis. The patient declined a lymph node biopsy. A course of superficial radiotherapy was given with some regression of the tumour and healing of the ulcers, but within six months the indurated erythema and scaling had recurred and extended from the spine to the submammary region on the left side. She died in December 1983. Permission to carry out necropsy was refused.

\section{Pathology}

Histological sections of the skin biopsy specimens in all three cases were similar. In each case acanthosis, papillomatosis, some hyperkeratosis, and focal ulceration had occurred (fig 3 ). Within the epidermis and dermis there were multiple nests of tumour cells which had smaller more darkly staining nuclei and less cytoplasm that adjacent squamous cells (fig 4). Many cells had clear cytoplasm and contained glycogen. Some nests in case 1 showed areas of attempted keratinisation with dyskeratotic cells at the periphery of the nest and keratinous debris in the centre. The cells in such nests showed a greater amount of nuclear pleomorphism, hyperchromasia, and abnormal mitotic figures than elsewhere in the tumour. A minor degree of acantholysis was also present in some areas. Mitoses were common in all the tumours, and occasional giant cells were seen. A variable number of small ductal lumina could be identified within some nests of neoplastic cells in all cases. The tumour stroma showed some deposition of alcian blue reactive acid mucopolysaccharides, and in one case had a focally prominent myxoid appearance. All cases showed tumour within lymphatic channels in the dermis (fig 5).

The post mortem examination of case 1 showed a large infected ulcer in the left inguinal area in the centre of a scaly hyperkeratotic lesion, as previously described. Microscopy confirmed very extensive residual malignant eccrine poroma of the thigh. The tumour was deeply infiltrative and had eroded the left femoral artery. The tumour extended into the pelvis, where it was adherent to the sigmoid colon and sur- 
rounded both the left and right iliac veins. Para-aortic and hilar lymph nodes were enlarged and contained metastatic tumour. There were microscopic deposits of metastatic tumour in the lungs and adrenal glands.

The inguinal lymph nodes from case 2 contained metastatic malignant eccrine poroma.

\section{Discussion}

Primary malignant tumours of the eccrine sweat glands are rare; they occur in about one of every 13000 specimens received in a dermatopathology laboratory. ${ }^{4}$ In a recent study of 35 cases of eccrine adenocarcinoma ${ }^{4}$ over $50 \%$ (18 cases) were of the eccrine porocarcinoma (malignant eccrine poroma) type. At least 59 cases of malignant eccrine poroma have been reported, ${ }^{56}$ of which 11 have shown lymph node metastases. Four of these cases also showed visceral metastases. We have added our two cases showing evidence of metastatic tumour. The table presents the clinical details.

Of the reported cases showing metastatic malignant eccrine poroma, all occurred on the buttock or lower limb. The sex distribution is about equal. The average age of these patients is 71 years, compared with an average age of 66 years for all reported cases of malignant eccrine poroma. The duration of the lesion in metastasising $v$ non-metastasising tumours is difficult to assess as the clinical data are incomplete in the reported cases; it is our impression, however, that metastasising tumours are present for a considerably longer time than non-metastasising tumours. This may be reflected in the older age of the patients with metastasising tumours.

Our three patients had certain clinical features in common with many of the previously reported cases. In each case the lesions comprised an extensive unilateral area of indurated erythema with central verrucous plaques or papules. The lesions tended to ulcerate. The lymphatic blockage seen histologically may explain the peripheral oedema and the translucent papules reminiscent of lymphangiomata that were seen in cases 1 and 3 .

Intraepidermal cell nests are a common feature of malignant eccrine poroma but are seen in many other skin tumours. ${ }^{3}$ In this tumour the epidermotropism is probably caused by the intrinsic nature of the neoplastic cells, which originate from the intraepidermal portion of the eccrine sweat duct. This type of spread may explain the tendency for the tumour to recur after surgical excision or radiotherapy and also its propensity for infiltration into adjacent skin, so that ultimately large areas of skin are affected. In case 1 the tumour spread directly into the pelvic cavity and extended to the contralateral iliac vein. Similar direct extension to the pelvis has been reported before. ${ }^{7}$

In the case of metastasising malignant eccrine poroma radiotherapy has been uniformly unsuccessful in treating the primary skin lesion. In case 1 the clinical impression was, in fact, that it may have worsened the situation. Wide local excision may be adequate treatment when the lesion is small. By the time a patient presents, however, the tumour often covers a large area, making complete excision very difficult.

Case 1 was initially misinterpreted as intraepidermal squamous cell carcinoma. Some tumour nests showed central necrosis, with the surrounding cells showing some dyskeratosis and Bowenoid changes. This feature is mentioned in other reports, ${ }^{56}$ although Mehregan et $\mathrm{al}^{4}$ state that one of the features of malignant eccrine poroma is the lack of keratinisation. The presence of keratinisation in these tumours remains a controversial issue.

In view of the characteristic clinical and histopathological features of this tumour we advocate strict use of terminology for malignant eccrine tumours and support the proposal that these tumours be divided into four distinct categories: malignant

Table Metastasising malignant eccrine poroma: review of published reports

\begin{tabular}{|c|c|c|c|c|c|c|}
\hline \multirow[b]{2}{*}{ Author } & \multirow[b]{2}{*}{ Age and sex } & \multirow[b]{2}{*}{ Location } & \multirow[b]{2}{*}{ Duration } & \multicolumn{2}{|l|}{ Metastases } & \multirow[b]{2}{*}{ Treatment } \\
\hline & & & & Lymph nodes & Viscera & \\
\hline $\begin{array}{l}\text { Krinitz } \\
\text { Grosshans et } a l^{8} \\
\text { Gschnait et } a l^{9} \\
\text { Mehregan et } a l^{4} \\
\text { Current paper, case } 1 \\
\text { Pinkus } \text { et } a l^{1} \\
\text { Akano et } a l^{10} \text { and Miura } \\
\text { Hadida } \text { et } a l^{12}\end{array}$ & $\begin{array}{l}77 / \mathrm{F} \\
84 / \mathrm{F} \\
69 / \mathrm{M} \\
63 / \mathrm{M} \\
60 / \mathrm{M} \\
82 / \mathrm{F} \\
69 / \mathrm{M} \\
78 / \mathrm{F}\end{array}$ & $\begin{array}{l}\text { Left leg } \\
\text { Left foot } \\
\text { Right foot } \\
\text { Foot } \\
\text { Left thigh } \\
\text { Left ankle } \\
\text { Right calf } \\
\text { Left leg }\end{array}$ & $\begin{array}{l}50 \text { years } \\
11 / 2 \text { years } \\
50 \text { years } \\
\text { Several years } \\
9 \text { years } \\
4 \text { years } \\
12 \text { years } \\
20 \text { years }\end{array}$ & $\begin{array}{l}+ \\
+ \\
+ \\
+ \\
+ \\
+ \\
+ \\
+\end{array}$ & $\begin{array}{l}+ \\
+ \\
+ \\
+ \\
+ \\
- \\
-\end{array}$ & $\begin{array}{l}\text { ? } \\
\text { Chemotherapy } \\
? \\
\text { Radiotherapy } \\
\text { ? } \\
\text { Radiotherapy } \\
\text { Radiotherapy } \\
\text { to lymph nodes }\end{array}$ \\
\hline $\begin{array}{l}\text { Mehregan et } a l^{4} \\
\text { Bottles et al } \\
\text { Shaw et } a l^{5} \\
\text { Shaw et } a l^{5} \\
\text { Current paper, case } 2\end{array}$ & $\begin{array}{l}58 / \mathrm{F} \\
60 / \mathrm{M} \\
61 / \mathrm{F} \\
85 / \mathrm{F} \\
76 / \mathrm{M}\end{array}$ & $\begin{array}{l}\text { Buttock } \\
\text { Thigh } \\
\text { Foot } \\
\text { Loin } \\
\text { Thigh }\end{array}$ & $\begin{array}{l}6 \text { years } \\
2 \text { years } \\
40 \text { years } \\
? \\
2 \text { years }\end{array}$ & $\begin{array}{l}+ \\
+ \\
+ \\
+ \\
+\end{array}$ & $\begin{array}{l}- \\
- \\
- \\
-\end{array}$ & $\begin{array}{l}\text { Radiotherapy } \\
? \\
? \\
\text { Excision }\end{array}$ \\
\hline
\end{tabular}


eccrine poroma; syringoid eccrine carcinoma; mucinous eccrine carcinoma; and clear cell eccrine carcinoma. ${ }^{4}$ The malignant counterpart of an eccrine poroma is variously called an epidermotropic eccrine carcinoma, ${ }^{1}$ an eccrine porocarcinoma, ${ }^{13}$ or a malignant eccrine poroma. ${ }^{56}$ Although we favour the last term because of its simplicity, we think it is more important to distinguish this tumour from other malignant eccrine tumours than to dispute terminology. Only by strict classification of the malignant eccrine tumours will progress be made in assessing treatment and prognosis.

We thank Drs JS Pegum, H Baker, MEJ Hackett, HF Hope-Stone, BS Mantell, and BC Sommerlad who looked after the patients. We are grateful to the photographic departments of the London Hospital for photographic help and to Mrs E Vasey for typing the manuscript.

\section{References}

1 Pinkus H, Mehregan AH. Epidermotropic eccrine carcinoma. A case combining features of eccrine poroma and Paget's dermatosis. Arch Dermatol 1963;88:597-606.

2 Pinkus H, Rogin JR, Goldman P. Eccrine poroma: tumour exhibiting features of the epidermal sweat duct unit. Arch Dermatol 1956;74:511-21.
3 Darley CR, Pegum JS, Pollock DJ. Epidermotropic eccrine carcinoma. J R Soc Med 1983;76:616-8.

4 Mehregan AH, Hashimoto K, Rahbari H. Eccrine adenocarcinoma. A Clinicopathologic study of 35 cases. Arch Dermatol 1983;119:104-14.

5 Shaw M, McKee PH, Lowe D, Black MM. Malignant eccrine poroma: a study of twenty-seven cases. $B r J$ Dermatol 1982;107:675-80.

6 Bottles K, Sagebiel RW, McNutt NS, Jensen B, Deveney K. Malignant eccrine poroma. Case report and review of the literature. Cancer 1984;53:1579-85.

7 Krinitz K. Malignes intraepidermales ekkrines porom. Z Hautkr 1972;47:9-17.

8 Grosshans E, Vetter JM, Capesius C. Poromes eccrines malins. Annales d'Anatomie Pathologique 1975;20:381-94.

9 Gschnait F, Horn F, Lindlbauer R, Sponer D. Eccrine porocarcinoma. J Cutan Pathol 1980;7:349-53.

10 Akano A, Nagakawa T, Kikuchi Y. Epidermotropic eccrine carcinoma. Rynsho Hifu-Hinyokika 1967;21:43-8.

11 Miura Y. Epidermotropic eccrine carcinoma. Japanese Journal of Dermatology (Series B) 1968;78:226-30.

12 Hadida E, Sayag J, Vallette P, Chandon JP. Poroepithelioma avec metastases ganglionnaires. Bulletin de la Société Francaise de Dermatologie et de Syphiligraphie 1972;79:271-2.

13 Mishima Y, Morioka S. Oncogenic differentiation of the intraepidermal sweat duct: eccrine poroma, poroepithelioma and porocarcinoma. Dermatologica 1969;138:238-50.

Requests for reprints to: Dr JF Ryan, Histopathology Department, Chase Farm Hospital, The Ridgeway, Enfield, Middlesex EN2 8JL. England. 